
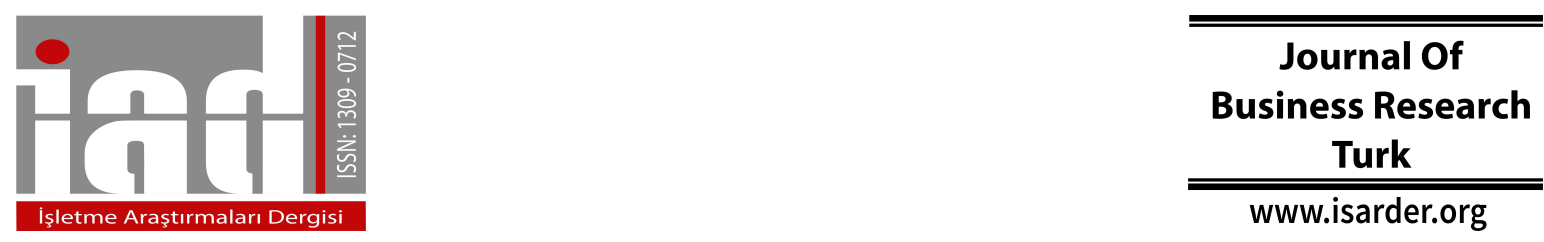

\title{
The Effect of Democratic Leadership on Organizational Cynicism: A Study on Public Employees
}

\author{
Fatma INCE \\ Mersin University \\ Information Business Management \\ Mersin, Turkey \\ orcid.org/0000-0002-0628-5858 \\ fatma_ince@yahoo.com
}

\begin{abstract}
This study assessed the relationships between democratic leadership and organizational cynicism among the public employees in the sample. The correlation value shows that there is a negative relationship between variables. Also, the democratic leadership can be considered as one of the predictors of the organizational cynicism with three sub-dimensions as cognitive, affective, and behavioral cynicism. Depending on the ttest results, there are not significant differences between two groups with the organizational cynicism and democratic leadership. Understanding the negative effect of the democratic leadership on the organizational cynicism indicates that the behavior of the leader can determine the perception of the employee directly.
\end{abstract}

Keywords: Democratic leadership, leader, cynicism, organizational cynicism, employees

\section{Introduction}

Leadership is about the establishing a clear vision and sharing that vision with others so that they will follow willingly. In addition, the leader can coordinate and balance the conflicting interests of all employees and supervisors (Denhardt, 1970). Leadership is one of the popular subjects that are currently receiving attention in terms of research, theory, and practice. That is because the different types of leadership styles exist in work environments due to the attribution theory (Northouse, 2018). Some kind of leadership is about the dark side of the leadership, while others focus on the positive outcomes (Denhardt, 2000). Democratic leadership is one of the positive leadership styles which is about the leader who has the authority to make the final decision of the group, while the team is involved in the decision-making process to determine what needs to be done and how it should be done (Woods, 2004).

The team equality and free flow of ideas are encouraged with the guidance and control of the leader. For this reason, the democratic leadership is also known as shared 
leadership or participative leadership (Starrat, 2001). This means that this kind of leader gives employees or team members a chance contributing to the decisions that are made and being a part of the group. The chance leads to higher effectiveness or productivity and group morale (Bhatti et al., 2012). The trivet of the democratic leadership has three critic points. First of all, there must be encouraged employees who even know the leader retains the final say over decisions, but share their ideas or opinions. Secondly, the employees with democratic leader feel more engaged in the process of the organization. Lastly, the creativity is encouraged and rewarded among employees, even though there is a leader who decides the situation or solves problem eventually (Gastil, 1994).

The democratic leadership literature focuses the benefits of democratic leadership as well as drawbacks of it. If the situations are unclear or operations are under a deadline, there may be some kind of communication failures which cause the uncompleted tasks (Rosenbaum and Rosenbaum, 1971). On the other hand, this kind of leadership needs the qualified employees to get decision-making process efficiency. Also, the satisfaction of the employees is mostly due to the participant level which is determined by the leader' initiative (Scontrino, 1972). On the contrary, democratic leadership is suitable for lots of organizations which have an effective communication network to help to contribute. According to Foels et al., (2000) that the democratic leadership is more satisfied than groups experiencing autocratic leadership as a result of the meta-analytic integration of their research.

In fact, there already exists a substantial literature addressing the effects of democratic leadership on positive organizational variables. One of them, Bhatti et al., (2012) emphasize the impact of autocratic and democratic leadership style on job satisfaction and they find that public teachers have a high level of job satisfaction rather than private teachers with the democratic leader. Another research is about the support of leader and trust relationship between sides. When the employees experience isolation or feel a sense of connectedness, the increasing vulnerability to traumatic stress disorders would exist (Ottenberg, 1987; Young and Erickson, 1988). Likewise, Kreitner \& Kinicki (1998) underline that lack of support from colleagues goes a long way to contributing to stress in an organization which could hinder the sense of belonging. Just the contrary Camman et al., (1983) observed that the extent to which a job gives an employee opportunity to interact with others enhances the sense of community at work. In the light of this information, it can be said that the democratic leadership can enhance positive attitudes and perceptions in an organization, while it can decrease the level of negative attitudes about an organization such as cynicism, conflict, and tardiness.

The organizational cynicism is one of the negative attitudes about an organization and it's the second variable of the study. Dean et al., (1998) remark the term of organizational cynicism and the authors defined it as "a belief that the organization lacks integrity" and "a negative affect toward the organization". These definitions draw attention the tendencies to disparaging and critical behaviors toward the organization that are consistent with negative beliefs and affect. Commonly, the organizational cynicism is considered as three subdimensions. First of all, the cognitive cynicism and it refers to disbelieving of the employees about their organizations. The reason for this perception is that there is a lack of some certain values such as fairness and sincerity in the practices or behaviors in the 
organization. Therefore, employees think that their organizations are such an unprincipled or immoral place (Naus et al, 2007). The second one is the affective cynicism and it refers to negative emotions about organizations. The employees feel disrespect, shame, anger, and boredom about their workplace, and so they do not respect towards organizations (Uysal and Gedik, 2017). Last of all, behavioral cynicism and it refers to an observable side of the organizational cynicism that includes employees' fierce criticisms of the organization such as belittlement, condescension, and denigration. The efficiency of the employees and organization both tend to decrease, because of the feeling alienated from an organization (Brandes et al., 2008).

In the organizational cynicism literature, the support affects the perception of cynicism negatively (Byrne and Hochwarter, 2008), as well as the procedural and interactional justice (Bernerth et al, 2007). The researches show that perceived support can lead the higher performance among the cynics' employees. Unsurprisingly, negative conditions like insecure work environment may cause the performance-decreasing for the cynics employees. The organizational cynicism especially occurs in organizational change conditions due to the uncertainty and fear. Such a situation, both leader, and employee can fell cynical toward organization; their performance can be affected negatively as a result of (Rubin et al, 2009). Because of the relationships between perceptions and performance, the organizational cynicism may interfere in and damage the person-organization fit (Neves, 2012). Therefore, the employees should be empowered with positive perceptions such as job satisfaction, commitment, and trust, instead of negative attitudes (Chiaburu et al, 2013). Further to that, supportive leadership styles like ethical leadership can affect the organizational cynicism negatively (Akan et al, 2014). In the light of this information, the relationships the organizational cynicism and democratic leadership are investigated in this study.

\section{Materials And Methods}

Firstly, the problem of the study and its importance are given in this part, and then the scales and their measurement take part. Lastly, the information about the sample of the study is shown before the results.

\section{The problem of the study and its importance}

The purpose of this study is to assess certain factors predicting the organizational cynicism as well as to determine the levels of organizational cynicism. For this purpose, perceived organizational cynicism, with three sub-dimensions as cognitive, affective and behavioral is accepted as the dependent variable. Also, democratic leadership is considered as the independent variable. In addition, the age, gender, and marital status, known as demographic factors, are analyzed as independent variables. Therefore, the relational screening model is used for this study.

Democratic leadership has not analyzed as a predictor of organizational cynicism before. Thusly, the main aim of the study is to contribute to the literature through the answering various questions. Here the problem of the current study is defined as identifying the levels of the organizational cynicism and demographic factors that are characteristic of employees in light of their perception of a democratic leader, and this could be achieved by answering the following questions: 
-What are the levels of the organizational cynicism and democratic leadership among employees?

- Does democratic leadership predict organizational cynicism?

- Are there significant differences in the level of variables among employees due to the demographic factors?

According to these questions, the hypotheses developed for research can be shown as below:

Hypothesis 1: There is a relationship between the democratic leadership and the organizational cynicism.

Hypothesis 2: The democratic leadership affects organizational cynicism negatively.

Hypothesis 3: There is a statistically significant difference between groups in terms of organizational cynicism.

Hypothesis 4: There is a statistically significant difference between groups in terms of democratic leadership.

\section{Scale and measurement}

The democratic leadership scale was developed by Terzi (2012) and then used in various researches (Bozdoğan and Sağnak, 2011; Terzi and Çelik, 2016). On the other hand, the organizational cynicism scale is developed by Dean et al. (1998) and has three sub-dimensions as cognitive, affective and behavioral. In addition, the scale is revised to the local culture by Karacaoğlu and İnce (2013).

For the first problem of the study, the frequency and percentage distribution of the variables have been observed to see what the features of the sample are. For the second problem, multiple regression analysis is used to understand which are considered to predict the organizational cynicism. For the third problem, the group tests are used to analyze how are the variables, which include gender, marital status, and age, differences between groups.

\section{Study sample}

The study has been conducted on the public employees in a state finance organization in Mersin. The study group of the research consists of 135 employees working in a public institution. The sampling method of the study is complete inventory counts due to the small population.

\section{Results and Discussion}

Firstly, study sample is analyzed to show the sample pattern. According to the results of descriptive statistic, the percentage of the male (58\%) is more than female by a narrow margin (42\%). Otherwise, the biggest part of the participants is seen between 35 and 42 ages (39\%). Lastly, marital status of the participant is mainly shown as married (77\%).

Then the reliability and validity analyses are used to assess the scales. Factor analysis results show that there is a linear relationship between variables. So, it can be said that there is a true correlation between variables and factors due to the lack of multicollinearity. Total variance explained that three factors account for $75 \%$ of the variance. In additionally, Kaiser Meyer Olkin (KMO) test show the strength of relationship among the variables with 
0,882 level (p:0,000). It is common to consider a result that account for $60 \%$ for KMO and $50 \%$ for explained total variance as satisfactory for social sciences (Ferguson and Cox, 1993). According to the factor analysis of the model, 3 factors extracted which have 125,6 chi-square level and 0,000 p-value in goodness of fit test. Moreover, KMO measure of sampling adequacy is 0,899 while Barlett's Test of approximate chi-square 1123 level which is significant at 0,05 level of significance. The results show that the sample is adequate to continue the tests due to the appropriateness of factor analysis. Also, to assess the reliability of the scales, Croanbach's Alpha is used and the analysis show that the scales refer to the consistent measure of the democratic leadership (Cronbach's $\alpha: 0,956$ ) and organizational cynicism (Cronbach's $\alpha$ : 0,928).

In the research, the democratic leadership is the independent variable, while the organizational cynicism is the dependent variable. Table 1 shows the results of descriptive analyses of the main variables and sub-dimensions.

Table 1. Descriptive Analyses of Variables

\begin{tabular}{llllll}
\hline Variables & $\begin{array}{l}\text { Democratic } \\
\text { leadership }\end{array}$ & $\begin{array}{l}\text { Organizational } \\
\text { cynicism }\end{array}$ & $\begin{array}{l}\text { Cognitive } \\
\text { cynicism }\end{array}$ & $\begin{array}{l}\text { Affective } \\
\text { cynicism }\end{array}$ & $\begin{array}{l}\text { Behavioral } \\
\text { cynicism }\end{array}$ \\
\hline Mean & 3,728 & 2,281 & 2,265 & 1,894 & 2,685 \\
Std. Dev. & 0,440 & 0,743 & 0,940 & 0,885 & 0,839 \\
N:135 & & & & & \\
\hline
\end{tabular}

The means of all variables are nearly the midpoint of 5 points Likert Scale which includes strongly disagree for 1 , disagree for 2 , neither agree nor disagree for 3 , agree for 4 , strongly agree for 5 . However, the Likert scale of democratic leadership includes never for 1 , rarely for 2 , sometimes for 3 , often for 4 , and very often for 5 . The highest mean value can be seen in the democratic leadership among all variables (Table 1).

Table 2. Correlation Analyses of Democratic Leadership and Organizational Cynicism

\begin{tabular}{|c|c|c|c|c|c|c|}
\hline Variables & & 1 & 2 & 3 & 4 & 5 \\
\hline \multirow[t]{2}{*}{ 1.Democratic leadership } & $\mathrm{r}$ & 1 & & & & \\
\hline & $\mathrm{p}$ & & & & & \\
\hline \multirow[t]{2}{*}{ 2.Cognitive cynicism } & $\mathrm{r}$ & $-0,334 * *$ & 1 & & & \\
\hline & $\mathrm{p}$ & 0,000 & & & & \\
\hline \multirow[t]{2}{*}{ 3.Affective cynicism } & $\mathrm{r}$ & $-0,156$ & $0,675^{* *}$ & 1 & & \\
\hline & $\mathrm{p}$ & 0,071 & 0,000 & & & \\
\hline \multirow[t]{2}{*}{ 4.Behavioral cynicism } & $\mathrm{r}$ & $-0,261 * *$ & $0,430 * *$ & $0,532 * *$ & 1 & \\
\hline & $\mathrm{p}$ & 0,002 & 0,000 & 0,000 & & \\
\hline \multirow{2}{*}{ 5.Organizational cynicism } & $\mathrm{r}$ & $-0,301 * *$ & $0,852 * *$ & $0,880 * *$ & $0,769 * *$ & 1 \\
\hline & $\mathrm{p}$ & 0,000 & 0,000 & 0,000 & 0,000 & \\
\hline
\end{tabular}


As can be seen in the correlation table, there are several significant correlations between all dimensions without the affective cynicism. In addition to that, all variables in the table exert a highly significant $(p<0,01)$ correlations with each other. The correlation coefficients and their significance levels can be seen clearly from the first column named democratic leadership. The total perception of democratic leadership has significant correlations with all the variables about organizational cynicism without affective cynicism.

The correlation values discuss mainly in three parts as the high degree, moderate degree, and low degree. If Pearson's Correlation value is -.30 to -.39 , it is considered as a moderate negative relationship, while the value is named weak from -.20 to -.29 point (Nakip, 2013). From this point of view, the correlations between democratic leadership and organizational cynicism are negative moderate relationship (r:-0,301; $\mathrm{p}: 0,000)$. Therefore, the hypothesis about the relationships between variables is accepted (Hyp. 1).

Table 3. Regression Analysis of Democratic Leadership and Organizational Cynicism

\begin{tabular}{|c|c|c|c|c|c|c|c|c|}
\hline $\begin{array}{l}\text { Independent } \\
\text { Variables }\end{array}$ & $\boldsymbol{\beta}$ & $\mathbf{t}$ & Sig. & $\mathbf{R}$ & $\mathbf{R}^{2}$ & $\mathbf{F}$ & Sig. & Result \\
\hline Constant & 3,116 & 13,143 & 0,000 & & & & & \\
\hline $\begin{array}{l}\text { Democratic } \\
\text { Leadership }\end{array}$ & $-0,224$ & $-3,643$ & 0,000 & & & & & \\
\hline Regression Mo & el Y (Or & ganizatiol & cynicis & $\begin{array}{l}-0,301 \\
): 3,116\end{array}$ & $\begin{array}{r}0,091 \\
-(0,22\end{array}$ & $\begin{aligned} & 13,268 \\
* & \text { Democr }\end{aligned}$ & $\begin{array}{r}0,000 \\
\text { atic lead }\end{array}$ & $\begin{array}{l}\text { Accept } \\
\text { rship) }\end{array}$ \\
\hline
\end{tabular}

According to the regression model, the democratic leadership affects organizational cynicism negatively. It means that hypothesis 2 is accepted. The results of the multiple regression analysis clearly document the democratic leadership as a negative predictor of organizational cynicism in this sample $\left(\mathrm{R}^{2}: 0,091 ; \mathrm{p}: 0,000\right)$.

Also, normality test is used to determine the data set is well-modeled by a normal distribution. Therefore, the skewness and kurtosis measures are used to characterize the location and variability of the data set and it is determined that skewness values are $-0,69$ and 0,00 ; kurtosis values are $-0,47$ and 0,76 . The skewness for a normal distribution is between $-1,5$ and $+1,5$, while the kurtosis for a normal distribution is between -2 and +2 (George and Mallery, 2010). So the values of the skewness and kurtosis are acceptable to continue the data analyses for this data.

According to the t-test and one-way ANOVA results, there are no significant differences between the groups with the democratic leadership in terms of gender (F: 0,164; p: 0,864), marital status (F: 0,041, p: 0,680) and age (F: 0,370; p: 0,544). So, the results of the test indicated that the common perception of the democratic leadership and organizational cynicism came mid in general, it also indicated that there are no statistically differences on the level of $(\alpha=0.05)$ attributed to the variables of gender marital status and age. Thus, the hypothesis about the group differences is not accepted for the organizational cynicism and democratic leadership (Hyp. 3 and 4). 


\section{Conclusion}

The style of leadership is seen as the pattern of behaviors engaged in by the leader when dealing with employees and the major motivator in an organization. The leadership literature discusses the term both traditional and modern ways from autocratic, democratic and laissez-faire to transformational, servant and mentor leadership. On the other hands, some researches focus the harmful or toxic side of the leader. In this research, democratic leadership is examined as one of the positive leadership styles. The maximum impact on results and on employees is supposed by the leader to achieve the goals timely. Also, the employees are needed the encouragement and being participants of decision making and connecting others effectively in a workplace. The lack of these requirements and the lack of guiding the works can cause negative attitudes like organizational cynicism.

From this point forth, it is examined that whether the democratic leadership affects the organizational cynicism or not in this study. According to the results, democratic leadership has a negative predictive value in the organizational cynicism with the three subdimensions which include cognitive cynicism, affective cynicism, and behavioral cynicism. It means that the democratic leadership affects the organization cynicism negatively within the scope of public employee's sample. Otherwise, employee's t-test to detect a statistical difference in means between two normally distributed populations show that there are not significant differences between two groups with the organizational cynicism and democratic leadership.

There is a consensus about the relationships between the leader and organizational perceptions of employees in the literature (Foels et al., 2000). Therefore, the negative relationship between democratic leadership and organizational cynicism can be seen similar to the literature (Neves, 2012). Because this kind of leadership refers to the positive outcomes, while it decreases the negative attitudes. The study of Bhatti et al. (2012) highlights this result and adds that leadership style has a positive impact on job satisfaction. Hence, the dyadic relationship between leader and employees can lead development as well as disappointment in accordance with the leader-member exchange theory. This is why the professionals should consider the behavior of the leader to achieve goals as well as to satisfy the employee' work-related human needs. On the other hand, the researches should prefer to choose the comparing study to understand which leadership style has the more effects on the negative workplace perceptions. In turn, the perceptional and behavioral studies can provide a unique insight into the minds of the professionals. 


\section{References}

Akan, D., Bektaş, F., \& Yıldırım, İ. (2014). "Sınıf öğretmeni algılarına göre etik liderlik ve örgütsel sinizm arasındaki ilişki”, NWSA-Education Sciences, 9(1), 48-56.

Bernerth, J. B., Armenakis, A. A., Feild, H. S., \& Walker, H. J. (2007). “Justice, cynicism, and commitment: A study of important organizational change variables", The Journal of Applied Behavioral Science, 43(3), 303-326

Bhatti, N., Maitlo, G. M., Shaikh, N., Hashmi, M. A., \& Shaikh, F. M. (2012). "The impact of autocratic and democratic leadership style on job satisfaction", International Business Research, 5(2), 192.

Bozdoğan, K., \& Sağnak, M. (2011). "İlköğretim okulu müdürlerinin liderlik davranışları ile öğrenme iklimi arasındaki ilişki”, Abant İzzet Baysal Üniversitesi Eğitim Fakültesi Dergisi, 11(1), 137-145.

Brandes, P., Castro, S. L., James, M. S., Martinez, A. D., Matherly, T. A., Ferris, G. R., \& Hochwarter, W. A. (2008). "The interactive effects of job insecurity and organizational cynicism on work effort following a layoff", Journal of Leadership \& Organizational Studies, 14(3), 233-247

Byrne, Z. S., \& Hochwarter, W. A. (2008). "Perceived organizational support and performance: Relationships across levels of organizational cynicism", Journal of Managerial Psychology, 23(1), 54-72.

Camman, Fischman, Jenkins, \& Wesh (1983) Assessing the attitude and perception of organization members. In S. Seashore (Ed.), Assessing organizational changes. John Wiley, New York.

Chiaburu, D. S., Peng, A. C., Oh, I. S., Banks, G. C., \& Lomeli, L. C. (2013). “Antecedents and consequences of employee organizational cynicism: A meta-analysis", Journal of Vocational Behavior, 83(2), 181-197.

Dean, J. W., Brandes, P., \& Dharwadkar, R. (1998). “Organizational cynicism”. Academy of Management Review, 23(2), 341-352.

Denhardt, R. B. (1970). "Leadership style, worker involvement and deference to authority", Sociology and Social Research, 54, 172-180.

Denhardt, R. B., \& Denhardt, J. V. (2000). "The new public service: Serving rather than steering", Public administration review, 60(6), 549-559.

Ferguson, E., \& Cox, T. (1993). Exploratory factor analysis: A users' Guide. International Journal of Selection and Assessment, 1(2), 84-94.

Foels, R., Driskell, J. E., Mullen, B., \& Salas, E. (2000). "The effects of democratic leadership on group member satisfaction: An integration", Small Group Research, 31(6), 676-701.

Gastil, J. (1994). "A definition and illustration of democratic leadership", Human Relations, 47(8), 953-975.

George, D., \& Mallery, P. (2010). SPSS for Windows Step by Step: A Simple Guide and Reference, Fourth Edition, Pearson Ed., Boston. 
Karacaoğlu, K., \& İnce, F. (2013). Pozitif Örgütsel Davranışın Örgütsel Sinizm Üzerindeki Etkileri: Kayseri İlindeki İmalat Sanayi İşletmelerinde Bir Uygulama. Süleyman Demirel Üniversitesi İktisadi ve İdari Bilimler Fakültesi Dergisi, 18(1), 181-202.

Kreitner, R. \& Kinicki, A. (1998). Organisational Behavior, McGraw-Hill, Boston.

Nakip, M. (2013). Pazarlama Araştırma Teknikleri, Seçkin Yayınları, Ankara.

Naus, F., Van Iterson, A., \& Roe, R. (2007). "Organizational cynicism: Extending the exit, voice, loyalty, and neglect model of employees' responses to adverse conditions in the workplace", Human Relations, 60(5), 683-718.

Neves, P. (2012). "Organizational cynicism: Spillover effects on supervisor-subordinate relationships and performance", The Leadership Quarterly, 23(5), 965-976.

Northouse, P. G. (2018). Leadership: Theory and practice. Sage publications, USA.

Ottenberg, D.J. (1987) Initiation of social support systems, Addison-Wesley, CA.

Rosenbaum, L. L., \& Rosenbaum, W. B. (1971). "Morale and productivity consequences of group leadership style, stress, and type of task", Journal of Applied Psychology, 55, 343-348.

Rubin, R. S., Dierdorff, E. C., Bommer, W. H., \& Baldwin, T. T. (2009). "Do leaders reap what they sow? Leader and employee outcomes of leader organizational cynicism about change", The Leadership Quarterly, 20(5), 680-688.

Scontrino, M. P. (1972). "The effects of fulfilling and violating group members' expectations about leadership style", Organizational Behavior and Human Performance, 8, 118-138.

Starrat, R. J. (2001). "Democratic leadership theory in late modernity: an oxymoron or ironic possibility?", International Journal of Leadership in Education, 4(4), 333-352.

Terzi, A. R. (2012). Liderlik davranışları ölçeği, Yayımlanmamış ölçek. Aktaran Terzi, A. R. ve Çelik, H. (2016). "Okul Yöneticilerinin Liderlik Stilleri ve Algılanan Örgütsel Destek İlişkisi: İlkokul ve Lise Öğretmenleri Üzerinde Bir Araştırma", Eğitim ve Öğretim Araştırmaları Dergisi, 5(2), 87-98.

Terzi, A. R. ve Çelik, H. (2016). "Okul Yöneticilerinin Liderlik Stilleri ve Algılanan Örgütsel Destek İlişkisi: İlkokul ve Lise Öğretmenleri Üzerinde Bir Araştırma”, Eğitim ve Öğretim Araştırmaları Dergisi, 5(2), 87-98.

Uysal H. T. and Gedik, A.İ. (2017). Effect of Cynical Individual Factor on the Reverse Mobbing Tendency: A Planned Behavior, Christiansen, B., \& Chandan, H. C. (Eds.). (2017). Handbook of Research on Organizational Culture and Diversity in the Modern Workforce, IGI Global, USA.

Woods, P. A. (2004). "Democratic leadership: drawing distinctions with distributed leadership", International journal of leadership in education, 7(1), 3-26.

Young, M.B. \& Erickson, C.A. (1988). "Cultural impediment to recovery PTSD in contemporary America", Journal of Stress, 431-443. 